\title{
Konsep perempuan shalihah pada lirik "Aisyah Istri Rasulullah" (Studi ketidakadilan analisis wacana Teun A. Van Dijk)
}

\author{
Islam Nur Kumala ${ }^{1 *}$, \\ ${ }^{1}$ UIN Sunan Kalijaga Yogyakarta
}

\begin{abstract}
The presentation of the lyrics in a song is a form of communication that requires meaning, through the massive lyrics of a song composed entitled "Aisyah Wife Rasulullah" which is discussed interestingly to be discussed in the realm of the meaning of the text, the context and the discourse. Through Teun A. Van Dijk's discourse analysis, a certain condition can also be understood as an injustice process, in which to expose the injustice it is done in 3 ways, namely by text analysis, context analysis and social discourse analysis. The importance of understanding a text with this discourse analysis is able to open a broader paradigm of problems in human life, especially the concept of injustice. As in the phenomenon of the song "Aisyah wife of the Prophet Muhammad" which produces a social discourse that women are righteous physically and who always accompany their husbands. This is said to be injustice in religion which has discussed the relationship between partners, as well as the measure of happiness in the household is not measured by women's physicality, as the concept of shalihah according to religion. So, the focus of this research is only to expose the injustices that occur in the text and the context of the discourse about the meaning of "shalihah" in the lyrics of "Aisyah, the wife of the Prophet". Keyword: discourse analysis, injustice, shalihah, song, Van Dijk.

Abstrak: Penyajian lirik dalam sebuah lagu merupakan salah satu bentuk komunikasi yang penuh makna. Lirik lagu gubahan berjudul "Aisyah Istri Rasulullah" yang masif diperbincangkan menarik untuk dibahas dalam ranah makna teks, konteks, dan wacananya. Melalui analisis wacana Teun A. Van Dijk suatu kondisi tertentu juga mampu dipahami sebagai suatu proses ketidakadilan, dimana untuk membongkar ketidakadilan tersebut dilakukan dengan 3 cara, yaitu dengan analisis teks, analisis konteks dan analisis wacana sosial. Pentingnya memahami suatu teks dengan analisis wacana ini, mampu membuka paradigma lebih luas tentang permasalahan dalam kehidupan manusia, khususnya konsep ketidakadilan. Seperti halnya dalam fenomena lagu "Aisyah Istri Rasulullah" yang menghasilkan wacana sosial bahwa perempuan shalihah ialah yang baik secara fisik dan yang senantiasa menemani suami. Hal ini dikatakan ketidakadilan dalam agama yang telah membahas kerelasian antar pasangan, serta ‘tolak ukur kebahagiaan dalam rumah tangga bukanlah diukur dari fisik perempuan, sebagaimana konsep shalihah menurut agama. Maka, fokus penelitian ini hanyalah pembongkaran ketidakadilan yang terjadi dalam teks maupun konteks wacana tentang makna "shalihah" pada lirik "Aisyah Istri Rasulullah".
\end{abstract}

Kata Kunci: analisis wacana, ketidakadilan, lagu, shalihah, Van Dijk

"Corresponding Author: Islam Nur Kumala | nurkumala.alhunain@gmail.com | Fakultas Dakwah dan Komunikasi Universitas Islam Negeri Sunan Klijaga, Jl. Marsda Adisucipto, Daerah Istimewa Yogyakarta, Indonesia 


\section{Pendahuluan}

Dunia permusikan diawal hingga pertengahan tahun 2020 menjadi ramai diperbincangkan di Indonesia, yaitu melalui hadirnya lagu dengan gubahan lirik baru dari salah satu penikmat dan kreator youtube, yang bernama Vitaminbie (Mr. Bie). Lagu yang bersumber dari salah satu band di Malaysia, yakni Projector Band, dengan judul asal yaitu "Aisyah, satu, dua, tiga cintamu" digubah menjadi "Aisyah Istri Rosulullah". Lirik gubahan baru tersebut menjadi santer dan viral tidak hanya di dunia internet saja (Dwiana, 2020; Magdegani, 2020; Supintou, 2020), melainkan juga di dunia nyata. Lagu dengan lirik yang menceritakan kehidupan percintaan Rosulullah bersama salah satu istri tercintanya, yaitu Sayyidah Aisyah tidak hanya menjadi konsumtif publik semata, tapi juga mengajak masyarakat untuk ikut membahas beberapa wacana yang digambarkan dalam lagu tersebut.

Berbagai pro dan kontra terhadap liriknya juga menjadi magnet tersendiri terhadap keviralan lagu tersebut. Terlihat beberapa viewernya dari pakar sosial, tokoh masyarakat hingga warganet biasa, berkali-kali membahas lagu tersebut di beranda sosial media mereka. Salah satu gejala yang ditimbulkan diantaranya santernya pembahasan masyarakat yang ingin seperti dan mengikuti sesuai yang digambarkan oleh lagu tersebut, entah menjadi tokoh Sayyidah Aisyah yang senantiasa menjadi istri sholihah bagi suaminya, atau memiliki suami yang seromantis Rosulullah.
Perbedaan perspektif tentunya dilatarbelakangi oleh banyak hal dalam memunculkan suatu pandangan tertentu. Begitupun yang terjadi ditengah tengah masyarakat terhadap lirik tersebut. Kondisi yang seperti ini, dibutuhkan suatu analisis yang tidak hanya membahas pada tataran teksnya saja melainkan juga terhadap bagaimana teks tersebut diwacanakan, yaitu pada ranah kontekstualnya.

Penulis akhirnya mencoba menelaah salah satu perspektif baru terhadap lirik tersebut, seperti pada postingan yang diangkat oleh tokoh perempuan yang sering membahas soal perempuan, yakni Kalis Mardiasih. Pada postingannya tertulis "Lagu Aisyah Istri Rasulullah viral karena liriknya romantis... ( dan jare kancaku, karena yang cover ayu ayu (red: dan kata teman saya karena yang cover cantik - cantik) ). Coba kalau liriknya : Aisyah, Engkau yang memprotes Abu Hurairah... "(Mardiasih, 2020) atau salah satu berita yang dimuat oleh media internet Satubanten.com yakni interview bersama perempuan yang gandrung dengan lirik lagu tersebut, hingga berkeinginan untuk mencontoh percintaan Sayyidah Aisyah dengan Rosulullah (Imans, 2020).

Disini terjadi pergolakan makna antara "teks" perempuan, makna yang hendak ditampilkan oleh pencipta lirik lagu serta wacana perempuan yang dipahami oleh masyarakat tertentu. Hal ini menjadi menarik untuk dibahas ketika masifnya "teks" perempuan diartikan justru sebagai bentuk ketidakadilan terhadap perempuan. Dari sini, perlu adanya pengkajian lebih dalam terhadap lirik 
lagu apakah demikian adanya? Maka untuk meganalisis struktur wacana yang terdapat dalam lirik lagu Aisyah Istri Rasulullah yang dikomentari oleh Kalis Mardiasih melalui akun Facebooknya, serta membongkar makna yang terdapat dalam teks tersebut, terdapat beberapa rumusan masalah sebagai berikut, yaitu (1) bagaimana analisis teks lirik lagu Aisyah Istri Rasulullah? dan bagaimana kognisi sosial Kalis Mardiasih dalam mengkritisi lagu tersebut di akun Facebooknya? serta (2) bagaimana analisis konteks sosial di masyarakat sehingga membentuk ketidakadilan yang ditampilkan oleh lagu tersebut?

\section{Kajian pustaka}

Adapun penelitian sebelumnya yang menjadi bahan perbandingan penelitian ini, yaitu dalam Jurnal E-Proceeding of Management Telkomsel University, oleh Pinny Oktariani Dedi Kurnia Syah Putra, S.Sos.I., M.Ikom yang berjudul "Representasi Materialisme (Analisis Wacana Kritis Teun A. Van Dijk Atas Lirik Lagu Buaya Buntung Karya Yoni Dores)", dimana menjelaskan bahwa lagu "Buaya Buntung" karya Yoni Dores menampilkan seorang laki-laki yang disebut buaya buntung. Melalui lirik lagu tersebut, materialisme direpresentasikan oleh pengarang didalam lirik lagu tersebut dan menggunakan genre dangdut sebagai media massa yang dianggap mampu mempengaruhi audiens. Akan tetapi, artikel tersebut hanya mengungkap 2 analisis Teun A. Van Dijk pada tataran makna teks dan konteks saja, sehingga yang dihasilkan hanyalah paradigma yang digunakan yaitu paradigma kritis yang memandang sesuatu yang memiliki sebuah tujuan untuk mempengaruhi sesuatu. (Oktariani \& Putra, 2017).

Sedangkan dalam artikel lain yaitu dengan judul "Lirik Lagu "2019 Ganti Presiden" Karya Sang Alang: Kajian Wacana Teun A. Van Dijk" dalam Jurnal milik UMSU (Universitas Muhammadiyah Sumatera Utara) oleh Diah Sugi Safitr, dimana penelitian ini membahas bahwa dalam lirik lagu "2019 Ganti Presiden" karya Sang Alang ketika ditelaah dari dimensi teks, kognisi sosial, dan konteks sosial memiliki tujuan sebagai kritik sosial terhadap kekecewaan dan keinginan sebagian besar masyarakat Indonesia untuk dapat segera mengganti presiden pada tahun 2019 (Safitri, 2019).

Kemudian dalam Jurnal Modelling, sebagai perbandingan penulis dengan objek yang berbeda, yakni tulisan Nurul Musyafa'ah dari Institut Agama Islam Sunan Giri Bojonegoro, Analisis Wacana Kritis Teun A. Van Dijk "Siswa Berprestasi Jadi Pembunuh", dimana menjelaskan bahwa media tentunya memiliki keberpihakan terhadap sesuatu, begitupun dengan koran yang memberitakan tindakan kriminal dengan pemberian judul pias yang secara sengaja mempersilahkan pembaca untuk menilai sendiri bagaimana berita tersebut digiring (analisis teks), tentunya bahasa - bahasa yang digunakan oleh media pun sesuai dengan penggiringan opini tersebut dan tentunya dipengaruhi oleh bagaimana ideologi dari media tersebut (kognisi sosial), dalam kondisi seperti ini media hendak memberikan kesan dalam 2 diksi yang bertolak belakang, antara siswa berprestasi dengan jadi pembunuh. Memberikan wacana kepada pembaca tidak semestinya seorang siswa berprestasi 
tidak membunuh, atau siswa berprestasi kenapa menjadi pembunuh (Analisis Wacana) (Musyafa'ah, 2017).

Dari keseluruh perbedaan antara artikel penulis terhadap artikel sebelumnya, selain dari proses analisis yang digunakan juga terhadap objek yang digunakan. Sehingga, hasilnyapun berbeda, dimana penelitian ini penulis menggunakan seluruh 3 bangunan telaah Teun A. Van Dijk dan dengan titik fokus pada studi keadilannya, objeknyapun lagu dan konteks serta wacana yang berkembang masif di masyarakat melalui salahsatu kritik sosial dari Kalis Mardiasih. sehingga muncul ketidakadilan dan konsep perempuan shalihah "baru".

\section{Metode}

Jenis penelitian ini adalah kajian penelitian kepustakaan (library research) yaitu melakukan penelitian dengan data-data yang bersumber dari literatur yang berupa buku, video, maupun teks - teks lain yang mendukung dan berkaitan dengan masalah yang akan diteliti secara sistematis, kritis dan analisis. Untuk mencapai tujuan penelitian tersebut, maka digunakan dengan pendekatan kualitatif yakni prosedur penelitian yang menghasilkan data deskriptif berupa kata-kata tertulis atau lisan yang diamati, dan dalam penelitian ini data tidak diwujudkan dalam bentuk angka namun data-data tersebut diperoleh dengan penjelasan dan uraian yang berbentuk lisan maupun tulisan (Meleong, 2002).

Teknik pengumpulan datanya, penulis menggunakan teknik pengumpulan dokumentasi atau survey kepustakaan serta study literatur, yang dimana survey kepustakaan yaitu menghimpun data yang berupa sejumlah literatur yang diperoleh. Sedangkan studi literatur yaitu mempelajari, menelaah dan mengkaji bahan pustaka yang berhubungan dengan masalah yang menjadi objek penelitian. Adapun dalam melakukan analisis datanya, yakni dengan cara menempuh teknik analisis wacana (discourse analysis) model Teun A. Van Dijk, yakni analisis yang sering disebut sebagai kognisi sosial. Dengan kata lain, analisis wacana Teun A. Van Dijk ini tidak sekedar mengamati teks semata, namun juga mengalisis praktik produksi teks tersebut. Dalam pendekatan ini, Van Dijk menggambarkan wacana dengan bangunan 3 dimensi, yaitu : teks, kognisis dan konteks sosial (Eriyanto, 2011).

\section{Hasil dan pembahasan}

Awal tahun 2020 Indonesia memiliki beberapa fenomena, bahkan terkena pandemi Covid-19 sejak Maret, puncaknya adalah disaat Ramadhan 1441 H. Manusia dihadapkan pada kondisi yang tidak semestinya, kondisi alam yang yang tidak bersahabat, yang juga memengaruhi kondisi lainnya, mulai dari pendidikan, perekonomian, peribadahan, hingga pada psikis dan mental manusia. Manusia dengan kondisi yang tidak seperti biasanya, harus dikurung diri dirumah, tidak diijinkan untuk kontak fisik selain dengan keluarga se rumah, hingga tidak diperbolehkan untuk keluar dari rumahnya sendiri kecuali mendesak. Kondisi seperti inilah yang kemudian menjadikan manusia ikut berpikir kreatif dan mengembangkan dirinya meski harus di rumah saja, mulai dari 
menciptakan koreo tarian, ngevlog, sampai mengkover lagu.

Saat yang sama pula sebuah lagu gubahan baru muncul dengan posisi terbaik di Youtube hingga beberapa hari. Suatu lagu yang awalnya biasa saja namun mampu menarik masyarakat untuk ikut merasakan liriknya, bahkan pada tataran "nge-halu". Proses yang menarik untuk dikaji lebih detil dengan analisis yang tepat. Seiring berjalannya waktu, lagu Aisyah Istri Rasulullah tersebut mampu memunculkan wacanawacana baru bagi dunia maya yang tengah dilanda pandemi korona sekaligus menahan kondisi puasa yang berbeda dari tahun-tahun sebelumnya. Suatu lagu yang mampu membawa proses ketidaksadaran diri manusia menjadi terbiasa mengulanginya, suatu lagu yang telah membuat sejarah baru dalam dunia permusikan mampu trending beberapa hari dan memiliki viewer jutaan dengan cover puluhan. Bukan menjadikan bosan, justru dianggap sebagai kebenaran atas isi liriknya (karena berulang - ulang dimainkan). Hal ini senada dengan yang dikatakan oleh Sigmund Freud, bahwa segala bentuk penilaian yang dihasilkan oleh manusia lebih banyak dipengaruhi oleh segenap alam bawah sadar dari manusia itu sendiri (Syahrul S., 2018).

Sebuah keviralan lagu yang justru menuai polemik dari segi sudut pandang makna, menuai kontroversi bagi para pengkritisi di bidangnya. Karya tetaplah karya dan harus diapreasi, lagu tetaplah lagu dengan segala lirik bahasanya, yang terkadang membuai, merayu dan lain sebagainya. Inilah yang disebut sebagai retorika persuasif yang dilakukan oleh komunikator atau pemilik pesan utama dalam menyebarluaskan pesan-pesan yang bermuatan nilai tertentu, baik dalam bentuk verbal maupun nonverbal, kepada oranglain yang tujuannya tiada lain adalah untuk diterima, dijalani dan atau mempengaruhi. (Ma'arif, 2010).

\section{Refleksi masyarakat}

Sesuai dengan tanggapan yang disampaikan oleh salah satu da'i sekaligus pengasuh Pondok Pesantren Al - Bahjah Cirebon, Buya Yahya melalui kajiannya dan dipublikasikan dalam channel YouTube Al-Bahjah. Buya Yahya menjelaskan tentang Islam mengajarkan kita untuk senantiasa berkhusnudhon (Al-Bahjah TV, 2020). Hal ini juga ditulis oleh Dani Garjitno dan Rifan Aditya dalam media Suara.com, bahwa bisa jadi penciptaan lirik tersebut adalah dengan niatan baik, bukan justru untuk merendahkan Rasulullah dengan bahasa - bahasa yang hasad dan vulgar terhadap jasad. "Berkenaan tentang kisah lagu Siti Aisyah itu, kita masih husnudzon, semoga yang membuat lagu itu niat baik, Yang menyusun syair tentang Siti Aisyah itu sampai dilagukan, meskipun saya tidak kenal, Insya Allah, niatnya baik. Mengangkat tentang Siti Aisyah. Agar orang mensuritauladani Siti Aisyah, alau benar syair yang itu, yang dilagukan itu, maka kita husnudzon, semoga yang membuat syair mendapatkan pahala besar dari Allah karena niatnya baik." Menurut Buya Yahya, sebaiknya lagu tersebut diubah juga dengan menampilkan sifat - sifat lain dari Sayyidah Aisyah, seperti cerdas, pandai, tegas, tanggap dan lain lain (Garjito \& Aditya, 2020).

Tidak hanya Buya Yahya yang menanggapi viralnya lirik lagu tersebut, beberapa tanggapan kritis juga muncul 
dari beberapa stakeholder dan influencer. Seperti dalam tulisan rubrik Mojok.co, yang berjudul "Analisis serius soal lagu Istri Rasulullah", ditulis oleh Abdul Gani pada 8 April 2020 lalu. Gani sengaja menanyakan balik kepada netizen dan masyarakat yang ingin menjadi laki - laki seperti Rasulullah atau menjadi perempuan seperti Sayyidah Aisyah seperti yang digambarkan dalam lirik. Gani menyarankan dalam tulisannya untuk bercermin dengan diri sendiri dulu. Perihal sudahkah mencontoh sisi lain dari kehebatan beliau? Tidak hanya fokus dan terhipnotis dengan ajakan yang tidak kita sadari untuk menikah muda, serta mewujudkan keromantisan dalam berhubungan suami istri saja (Gani, 2020). Jika melihat sejarah, memang masih banyak akhlak-akhlak Rasul dan istrinya yang harus dipahami betul oleh manusia, terutama dalam menghargai sesama manusia.

Bergeser kepada tanggapan yang justru lebih mengacu pada ketidakadilan yang ditonjolkan dalam lagu ini, yaitu kepada perempuan itu sendiri. Tokoh gender, dan pegiat media, Kalis Mardiasih tampil membawa wacana lain yang ia kritisi, yaitu terkait pelanggengan diri perempuan sendiri yang justru lebih gandrung ingin diseperti-Aisyah-kan fersi lirik lagu tersebut. Dalam salah satu postingannya di Facebook "Lagu Aisyah Istri Rasulullah viral karena liriknya romantis... (dan jare kancaku, karena yang cover lagunya ayu - ayu). Coba kalau liriknya : Aisyah, Engkau yang memprotes Abu Hurairah..." (Mardiasih, 2020). Melalui sosok Kalis yang telah membawa pengaruh bagi peningkatan hak-hak perempuan, serta yang aktif dalam menyuarakan kesetaraan gender, mencoba menyajikan kritikan-kritikan kepada masyarakat dengan bahasa sederhananya. Melalui akun media sosialnya, Kalis fokus pada pelabelan bahwa cantik itu fisik, paras penyanyi atau model video klipnya yang menjadikan salah satu sebab viewer lagu tersebut boom, serta konsep pemahaman dalam memaknai pesan secara mentah untuk menjadi Aisyah versi lagu tersebut.

Makna sholihah

Islam telah memberi penjelasan secara khusus terhadap makna perempuan, dimana al-qur'an menjelaskannya secara terpisah dalam suat yang bernama Al-Nisa' (perempuan). Adapun pembahasan kriteris shalihah, setidaknya tertera dalam surat yang sama pada ayat 34 . Dalam ayat tersebut dijelaskan bahwa sifat perempuan shalihah hanya ada dua, yaitu ta'at dan menjaga kehormatan. Lebih jelasnya, dua sifat tersebut memiliki penafsiran Qani'at dan Hafidzat lil Ghaib.

Kata Qanitat merupakan bentuk jama' dari kata "qanit" yang berarti "yang merendahkan diri kepada Allah" atau "yang taat" dan "yang tunduk". Taat artinya menurut perintah yang benar dan baik serta tidak berlawanan dengan perintah agama. Ayat ini memiliki muatan peraturan hubungan antar suami istri, sehingga kata qanitat yang ada di dalam ayat banyak diartikan taat kepada suami. Senada dengan penjelasan dalam QS. Al Ahzab: 35 "Sesungguhnya, laki-laki dan perempuan muslim, laki-laki dan perempuan mukmin, laki-laki dan perempuan yang tetap dalam 
ketaatannya." Artinya, qanit merupakan sifat seorang mukmin, maka seorang qanit adalah orang yang tetap berpegang pada Al Qur'an dan hadits, tanpa berpaling dari keduanya.

Sedangkan Hafidzat lil Ghaib memiliki arti wanita-wanita yang memelihara diri di belakang suaminya. Dalam tafsir Al-Maraghi sebab Allah memerintahkan demikian karena "bima hafidzallah" yakni supaya memelihara dirinya dengan tidak mentaati hawa nafsu mereka, inilah bentuk mentaati perintah Allah. Dalam pengambilan hikmah dari ayat ini, juga terkait tentang perintah untuk tidak menyebarkan rahasia antar suami istri. Demikian tidak hanya perempuan menutupi rahasia suami, suamipun wajib memelihara rahasia istri, seperti kesalahan karena menghilangkan harta suaminya. Seperti yang dijelaskan dalam salah satu hadits yang artinya: "Dan ia (wanita yang baik) tidak mengingkari suaminya dengan sesuatu yang dibencinya dalam (menjaga) diri dan hartanya" ('Adawiyah, 2010).

\section{Analisis wacana}

Banyak model analisis wacana yang diperkenalkan dan dikembangkan oleh para ahli, diantaranya analisis wacana yang dikembang oleh Roger Fowler dkk. (1979), Theo van Leeuwen (1986), Sara Mills (1992), Norman Fairclough (1998), dan Teun Van Dijk (1998). Dari sekian banyak model, yang paling banyak dipakai adalah model Teun A. Van Dijk, hal ini mungkin didasari karena Van Dijk menggunakan elemenelemen yang mudah untuk di aplikasikan (Eriyanto, 2011).

Kata wacana atau discourse berasal dari bahasa Latin yaitu discursus yang berarti lari kian - kemari (yang diturunkan dari dis- 'dari, dalam arah yang berbeda', dan currere 'lari'). Ismail Marahimin mengartikan wacan sebagai kemampuan untuk maju, yaitu menurut urut - urutan yang teratur dan semestinya, dan komunikasi buah pikiran, baik lisan maupun tulisan yang resmi dan teratur. Menurut Riyono Pratikto, proses berpikir seseorang sangat erat kaitannya dengan ada tidaknya kesatuan (unity) dan koherensi (coherence) dalam tulisan yang disajikannya. Semakin baik pola berpikinya pada umumnya semakin terlihat jelas adanya kesatuan dan oherensi tersebut. Sebuah tulisan adalah wacana, tetapi apa yang dinamakan wacan itu tidak perlu hanya sesuatu yang tertulis seperti diterangkan dalam kamus Websters bahwa sebuah pidato pun dikatakan sebagai wacan juga. Jadi, terdapat wacan lisan dan wacana tulisan (Sobur, 2001).

Henry Guntur Tarigan berpendapat bahwa istilah wacana dipergunanakan untuk mencakup bukan hanya percakapan atau obrolan, tetapi juga pembicaraan di muka umum, tulisan, serta upaya - upaya formal, seperti laporan ilmiah dan sandiwara atau lakon. Lalu, Samsuri menyatakan bahwa wacana ialah rekaman kebahasaan yang utuh tentang peristiwa komunikasi, biasanya terdiri dari seperangkat kalimat yang mempunyai hubungan pengertian yang satu dengan yang lain. Sehingga membahas wacana artinya membahas bahasa dan tuturan yang harus didalam rangkian kesatuan situasasi penggunaan yang utuh. Di sini, makn suatu bahasa berada pada rangkaian konteks dan situasi, seperti yang dikemukakan oleh Firth "Language as only meaningful in 
its context of situation". Oleh karena itu, ia berpendapat bahwa pembahasan wacan pada dasarnya merupakan pembahasan terhadap hubungan antara konteks - konteks yang terdapat di dalam teks. Pembahasan itu bertujuan menjelaskan hubungan antara klaimat atau antara ujaran (utterances) yang membentuk wacana (Sobur, 2001).

Perbedaan disiplin ilmu juga mampu mempengaruih gambaran makna pada kata wacana itu sendiri, seperti dalam sosiologi. Wacana utamanya menunjuk pada hubungan antara konteks sosial dari pemakaian bahasa. Pengertian linguistik sendiri, wacana diartikan sebagai unit bahasa yang lebih besar dari kalimat (Eriyanto, 2011). Sedangkan dipihak lain, pengertian wacana dapat ditinjau dari sudut sebuah komposisi atau karangan yang utuh, dan untuk mengetahui perbedaan suatu karangan, maka dengan mengetahui tujuan umumnya. Adapun tujuan umum dari suatu karangan dipengarui oleh dan ditentukan oleh kebutuhan dasar manusia, diantaranya ada 4 macam kebutuhan dasar yang dapat terpenuhi dengan karang - mengarang, yaitu untuk memberi dan memperoleh informasi, untuk meyakinkan seseorang mengenai suatu kebenaran dan mempengaruhi orang lain, untuk mendeskripsikan cita rasa suatu benda, hal atau bunyi, dan untuk menceritakan pada orang lain kejadian atau peristiwa yang terjadi, baik yang dialami sendiri maupun yang didengarnya dari orang lain.

Melalui tujuan umum inilah secara tradisional dibeda-bedakan bermacammacam karangan atau bentuk retorika. Secara sederhana, teori wacana menjelaskan sebuah peristiwa terjadi seperti terbentuknya sebuah kalimat atau pernyataan, karena itulah ia dinamakan analisis wacana. Sebuah kalimat bisa terungkap bukan hanya karena ada orang yang membentuknya dengan motivasi atau kepentingan subjektif tertentu (rasional atau irasional). Analisis wacana dimaksudkan sebagai suatu analisis untuk membongkar maksud maksud dan makna - makna tertentu, yang mana wacana diartikan sebagai upaya pengungkapan maksud tersembunyi dari sang subjek yang mengemukakan suatu pernyataan. Individu tidak dianggap sebagai subjek yang netral yang bisa menafsirkan secara bebas sesuai dengan pikirannya, karena sangat berhubungan dan dipengaruhi oleh kekuatan sosial yang ada didalam masyarakat. Maka digunakanlah bahasa sebagai medium netral yang terletak di di luar diri si pembicara. Bahasa dipahami sebagai representasi yang berperan dalam membentuk subjek tertentu, tema-tema wacana maupun strategi-strategi didalamnya. Oleh karena itu, analisis wacana dipakai untuk membongkar kuasa yang ada dalam setiap proses bahasa : batasan - batasan apa yang diperkenankan menjadi wacana, perspektif yang mesti dipakai, serta topik apa yang dibicarakan (Sobur, 2001).

Banyak model analisis wacana yang diperkenalkan dan dikembangkan oleh para ahli, diantaranya analisis wacana yang dikembang oleh Roger Fowler dkk., Theo van Leeuwen, Sara Mills, Norman Fairclough, dan Teun Van Dijk. Dari sekian banyak model, yang paling banyak dipakai adalah model Teun A. Van Dijk, hal ini mungkin didasari karena Van Dijk menggunakan elemenelemen yang mudah untuk di aplikasikan 
(Eriyanto, 2011). Model yang dipakai oleh Van Dijk disebut sebagai kognisi sosial yang istilahnya diadopsi dari pendekatan lapangan psikologi sosial, terutama untuk menjelaskan struktur dan proses terbentuknya suatu teks.

Menurut Van Dijk penelitian atas wacana tidak cukup hanya didasarkan pada analisis teks semata, karena teks hanya hasil dari suatu praktik produksi yang harus juga diamati. Akhirnya, Van Dijk membuat kerangka analisis wacana yang dapat didayagunakan, yang terdiri atas tingkatan atau struktur yang saling mendukung, ada 3 tingkatan, yakni :

a.) Struktur Makro, yaitu makna global/umum dari suatu teks yang dapat dipahami dengan melihat topik dari suatu teks. Tema wacana bukan hanya mencakup tentang isi, tapi juga sisi tertenu dari suatu peristiwa.

b.) Superstruktur, yaitu kerangka suatu teks; tentang bagaiman struktur dan elemen wacan itu disusun dalam teks secara utuh, dan

c.) Struktur Mikro yang merupakan makna wacana yang dapat diamati dengan menganalisis kata, kalimat, proposisi, anak kalimat, parafrase yang dipakai dan sebagainya.

Lalu, struktur/elemen wacana yang dikemukakan oleh Van Dijk ini dapat digambarkan sebagai beikut :

Tabel Elemen Analisis Wacana Model Teun A. Van Dijk (Eriyanto, 2011).

\begin{tabular}{|c|c|c|}
\hline Struktur wacana & Hal yang diamati & Elemen \\
\hline Struktur makro & $\begin{array}{l}\text { Analisis tentang makna global dari suatu teks } \\
\text { yang dapat diamati dari topik / tema yang } \\
\text { diangkat (tematik) }\end{array}$ & Topik \\
\hline Superstruktur & $\begin{array}{l}\text { Analisis kerangka suatu teks, seperti bagian } \\
\text { pendahuluan, isi, penutup dan kesimpulan } \\
\text { (skematik/alur) }\end{array}$ & Skema \\
\hline Struktur mikro & $\begin{array}{l}\text { Makna lokal dari suatu teks yang dapat diamati } \\
\text { dari pilihan kata, kalimat dan gaya yang } \\
\text { dipakai oleh suatu teks (semantik) }\end{array}$ & $\begin{array}{l}\text { Latar, detil, } \\
\text { maksud, pra- } \\
\text { anggapan, } \\
\text { nominalisasi. }\end{array}$ \\
\hline Struktur makro & $\begin{array}{l}\text { Analisis mengenai bagaimana pendapat } \\
\text { disampaikan (sintaksis) }\end{array}$ & $\begin{array}{l}\text { Bentuk kalimat, } \\
\text { koherensi dan } \\
\text { kata ganti }\end{array}$ \\
\hline Superstruktur & $\begin{array}{l}\text { Analisis mengenai bagaimana pemilihan kata } \\
\text { yang dipakai (stilistik) }\end{array}$ & Leksikon \\
\hline Struktur mikro & $\begin{array}{l}\text { Analisis tentang bagaimana dan dengan cara } \\
\text { apa penekanan dilakukan (retoris) }\end{array}$ & $\begin{array}{l}\text { Grafis, metafora } \\
\text { dan ekspresi }\end{array}$ \\
\hline
\end{tabular}

Analisis wacana dalam model Van Dijk terdapat 3 dimensi / bagian, yaitu :

1. Teks

Dalam dimensi teks, yang diteliti adalah bagimana struktur teks dan strategi wacana yang dipakai untuk menegaskan suatu tema tertentu. Adapun struktur dalam analisis teks terdiri dari 3 bagian, yaitu: struktur makro, superstruktur dan struktur mikro, seperti yang telah dijelaskan diatas. Lebih jelasnya adalah sebagai berikut : 

a. Tematik (Topik)
b. Skematik (Alur)
c. Semantik (Alur, Detil, Maksud, dan Praanggapan)
d. Sintaksis (bentuk kalimat, koherensi dan kata ganti)
e. Stilistik (Leksikon atau pemilihan kalimat)
f. Retoris (grafis dan metafora)

2. Kognisi Sosial

Setiap orang memiliki gambaran yang berbeda-beda mengenai realitas disekelilingnya. Persepsi sosial mampu menangkap arti objek-objek sosial dan kejadiankejadian yang dialami dilingkungan manusia. Manusia yang bersifat emosional memiliki penilaian terhadap sesuatu dan mengandung resiko (Mulyana, 2000). Sehingga dipastikan bahwa persepsi sosial dipengaruhi oleh berbagai hal, salah satunya adalah kognisi seseorang. Dalam dimensi kognisi sosial ini meneliti proses terjadinya suatu tema tersebut dengan melibatkan kognisi dari subyek atau da'i, yang dapat juga diartikan sebagai kesadaran mental dari da'i terhadap hasil tema yang disampaikan. Jadi, kognisi sosial ini tidak hanya membatasi perhatiannya pada struktur teks tapi juga bagaimana suatu teks tersebut di produksi (Eriyanto, 2011).

3. Analisis sosial (wacana sosial)

Wacana dipahami sebagai penetapan makna dalam domain tertentu. Semua tanda yang terdapat dalam suatu wacana merupakan momen-momen. Momen-momen tersebut merupakan mata jaringmata jaring dalam jaring lain, yang maknanya ditetapkan karena perbedaannya satu sama lain (Jorgensen \& Phillips, 2007). Sehingga ketika menentukan wacana dalam suatu penelitian dilakukan dengan pemusatan satu wacana pada suatu topik tertentu.

Lalu, Dalam dimensi ketiga adalah analisis sosial, yaitu wacana yang berkembang di masyarakat, sehingga untuk meneliti teks perlu dilakukan analisis intertekstual dengan meneliti bagaimana wacana tentang suatu hal diproduksi dan dikonstruksi dalam masyarakat (Eriyanto, 2011).

Proses analisis wacana terhadap lirik

Dari pembahasan yang dijabarkan diatas, didapatkan proses analisis sebagai berikut :

\section{Analisis Teks}

Menurut Van Dijk penelitian atas wacana tidak cukup hanya didasarkan pada analisis teks semata, karena teks hanya hasil dari suatu praktik produksi yang harus juga diamati. Akhirnya, Van Dijk membuat kerangka dalam menganalisis suatu teks dilakukan dengan 3 tingkatan yang saling berkaitan satu sama lain, pertama, struktur makro yang merupakan makna global atau makna secara umum dari suatu teks. Kedua, super struktur yang merupakan struktur wacana yang berhubungan dengan kerangka suatu teks. Ketiga, yang merupakan makna wacana yang 
bisa diamati dengan bagian kecil

dari suatu teks.

Tabel 2. Elemen Analisis Wacana Model Teun A. Van Dijk (Eriyanto, 2011).

\begin{tabular}{|c|c|c|}
\hline Struktur wacana & Elemen & Hasil temuan \\
\hline Struktur makro & Topik/tematik & $\begin{array}{l}\text { Aisyah. } \\
\text { Romantisnya cintamu dengan nabi } \\
\text { dengan baginda kau pernah main lari-lari } \\
\text { selalu bersama hingga ujung nyawa } \\
\text { kau di samping rasulullah }\end{array}$ \\
\hline $\begin{array}{l}\text { Super } \\
\text { Struktur }\end{array}$ & Skematik & $\begin{array}{l}\text { - Awal : } \\
\text { Mulia indah cantik }\end{array}$ \\
\hline Struktur mikro & $\begin{array}{l}\text { Latar, detil, } \\
\text { maksud, pra- } \\
\text { anggapan, } \\
\text { nominalisasi. }\end{array}$ & Sungguh sweet nabi mencintamu \\
\hline Struktur makro & $\begin{array}{l}\text { Bentuk kalimat, } \\
\text { koherensi dan } \\
\text { kata ganti }\end{array}$ & $\begin{array}{l}\text { Diviralkan oleh penyanyi nisa sabyan, cover } \\
\text { anisa rahman, cover adam (model klipnya } \\
\text { perempuan berlenggak - lenggok), cover via } \\
\text { vallen, cover nabila suaka dll. }\end{array}$ \\
\hline $\begin{array}{l}\text { Super } \\
\text { Struktur }\end{array}$ & Leksikon & Ya aisyah ya humairah \\
\hline Struktur mikro & $\begin{array}{l}\text { Grafis, metafora } \\
\text { dan ekspresi }\end{array}$ & $\begin{array}{l}\text { Kau istri tercinta ya aisyah, ya humairah } \\
\text { rasul sayang, kasih rasul cintamu }\end{array}$ \\
\hline
\end{tabular}

Tema dalam lagu ini yang diangkat oleh penggubah lagu dari aslinya adalah tentang kisah a. Tematik percintaan Rasulullah bersama salah 
satu istrinya Aisyah. Melalui lirik dengan kalimat "Romantisnya cintamu dengan Nabi" inilah yang memperkuat topik bahwa hubungan mereka begitu romantis. Kata "romantis" diartikan sebagai kebahagiaan. Sehingga menunjukkan bahwa tema awal lagu ini memang ingin disajikan sebagai kisah dari suatu hubungan percintaan dua manusia yang bahagia.

b. Skematik

Adapun Skematik yang dikisahkan dalam lagu ini berawal dari penjabaran fisik sosok Aisyah hingga dari mana background beliau (seperti sifat indah, cantik, berseri, kulit putih bersih, merahnya pipi). Pada puncaknya, dimana lirik ditampilkan tentang bagaimana keromantisan itu disetting oleh penggubah lagu, sampai pada pelabelan bahwa Aisyah perempuan yang senantiasa menemani Rasulullah. Hingga diakhiri pada lirik bahwa konsep seperti itulah sirrah (kisah) yang baik tentang istri yang dicintai suami.

c. Pra-Anggapan

Melalui beberapa ciri yang disebutkan, seperti cantik, manis, romantis, dan penurut, pengarang hendak menampilkan kecantikan seorang Istri yang begitu dicintai suami. Dalam pelanggengannya, disini sosok Aisyah dan Rasulullah dihadirkan (sebagai tokoh teladan) untuk menciptakan kebahagiaan dan keromantisan dalam hubungan percintaan.

d. Koherensi

Keterikatan dan

ketersalingan antara pra - anggapan terhadap lirik lagu, juga dikuatkan dengan adanya video - video penyanyi lagu dengan fisik "ayu", dimana hampir semua komentar dalam cover lagu tersebut dipenuhi dengan pujian, seperti dari Roy Hendro Sitepu dalam kolom komentar cover Grub Sabyan di You Tube (Sabyan, 2020) "Yang nyanyi cantik, suaranya pun cantik". Melalui komentar tersebut kata "cantik" menunjukkan pelabelan seseorang terhadap kondisi fisik.

e. Leksikon

Adapun pemilihan kata yang dipakai dalam lagu ini memakai "ya Aisyah ya Humairah" yang berarti pipi yang kemerah - merahan. Konsep fisik lagi yang diangkat oleh penggubah lagu terhadap sosok Aisyah dalam lagu ini menjadikan topik dari lagu ini semakin kuat. Pengibaratan perempuan dengan kondisi fisik pipi yang kemerahmerahan dijadikan sebagai salah satu tolak ukur kebahagiaan dalam berhubungan antara laki - laki dan perempuan.

f. Ekspresi Penekanan

Adapun puncak penekanan maknanya, terdapat pada ekspresi penekanan di kalimat "Rosul sayang, Rosul kasih cintamu”. Melalui kalimat ini terhadap makna bahwa semua yang terdapat dalam lirik sebelum kalimat tersebut, merupakan hal - hal yang Rasulullah kasihi dan sayangi. Artinya, jika yang memnuhi beberapa ciri yang dituangkan dalam lirik tersebut, tidaklah Rosul sayangi dan kasihi.

Teks dari lagu ini benarbenar dirancang sedemikian rupa 
agar penikmat mampu masuk dalam cerita tersebut. Sehingga melalui kata yang persuasif dan retorik mampu menarik penikmat untuk andil dalam proses pemublikasian lagu. Sehingga dalam hal ini adsense dan faktor ekonomi menjadi salahsatu yang memengaruhi proses teks ini dibuat.

\section{Analisis Kognisi Sosial Dari} Tanggapan Kalis Mardiasih Terhadap Lagu

Dimensi kognisi sosial ini mencoba meneliti proses terjadinya suatu tema tersebut dengan melibatkan kognisi dari subyek atau tokoh tertentu, yang dapat juga diartikan sebagai kesadaran mental dari subyek terhadap hasil tema yang disampaikan. Jadi, kognisi sosial ini tidak hanya membatasi perhatiannya pada struktur teks tapi juga bagaimana suatu teks tersebut di produksi (Eriyanto, 2011).

Dikutip dari salah satu bukunya, Kalis Mardiasih lahir di Blora, 16 Pebruari 1992. Saat ini, ia menulis di kolom mingguan milik detiknews dan untuk beberapa media digital lain seperti mojok.co dan DW Indonesia bertema Islam sehari - hari dan perempuan. Buku pertamanya, Berislam Seperti Kanak-Kanak yang terbit pada tahun 2018 oleh Gerakan Islam Cinta dan Convey Indonesia. Kalis terlibat dalam riset dan pengembangan narasi media sosial \#IndonesiaRumahBersama bersama Jaringan Nasional Gusdurian (Mardiasih, 2019).

Sedangkan dari Wikipedia, Kalis Mardiasih merupakan seorang penulis opini dan aktivis muda (NU), dia merupakan salah satu influencer di media sosial untuk kalangan anak muda millenial. Dalam wikipedia juga dijelaskan bahwa ia menulis sejak di kuliah karena desakan ekonomi, dimana ayahnya yang menguji ketahanan hidup Kalis dengan membiarkan anaknya kehabisan uang (Wikipedia, 2020).

Profil singkat dari sosok Kalis Mardiasih menunjukkan opini keseharian yang dimunculkan melalui nalar kritisnya merupakan tidak serta merta ada, begitupun saat menanggapi lagu Aisyah dengan lirik yang "mengkerdilkan" makna istri hanya berkisaran soal fisik dan domestik semata. Kebiasaan Kalis dalam menaggapi isu perempuan serta dipengaruhi dengan beberapa pengalaman hidupnya, Kalis ingin menyadarkan kepada viewer lagu Aisyah dan netizen yang ngehalu dengan lagu tersebut, untuk mencoba menelaah pasangan fenomenal ini (antara Rasulullah dan Sayidah Aisyah) dari sudut yang lain, seperti tanggapannya yang mengutarakana bagaimana jika ya Aisyah ya Humairah diganti dengan ya Aisyah yang meprotes Abu Hurairah (tentang 3 hal yang membuat sial, salah satunya adalah perempuan).

Lalu, tanggapan ini menuai banyak afirmasi dari emak - emak muda, yang ikut menyuarakan hak - hak perempuannya dikolom komentar, diantaranya dari Aqlal Lubada Faisyar "Coba di tambahi Aisyah Istri ketiga dari sembilan istrinya, yakin ibu - ibu gak ada yang menyanyikan", atau komentar Ifa Assyifa "Apalagi kalau liriknya Aisyah perang Jamal dengan Sayyid Ali, yo ancur", atau Zuhriyyah Hidayati "Lagu ini sarat intrik aliran / faham, itu pertama. Kedua, kecerdasan 
Aisyah blas ga ditonjolkan. Sayang banget."

Menelaah salah satu tulisan Abdul Gani, di Mojok.co edisi April, mengutip dari Paul Ricoeur dijelaskan bahwa untuk menilai atau memahami suatu pesan seharusnya melakukan distansi, sehingga subjektivitas tak mereduksi makna, sedangkan masyarakat bahwa dalam kisah lagu tersebut yang digambarkan adalah Rosulullah dan Sayyidah Aisyah. Sehingga psikoanalisis masyarakat pun tidak sadar bahwa Rasulullah dan Sayyidah Aisyah juga manusia biasa, meski tidak seperti manusia pada biasanya (Gani, 2020).

3. Analisis Wacana (Konteks Sosial) Terhadap Wacana "Perempuan Sholihah" Menurut Lagu

Sebagaimana yang diungkap oleh penggubah, Mr.Beie menyatakan bahwa salah satu tujuannya ialah mengenalkan anak-anak muda untuk sedikit mengetahui kehidupan dari Sayyidah Aisyah dan mampu untuk dijadikan pelajaran terutama anak-anak milenial (Aditia, 2020; Astika, 2020). Dengan trendingnya beberapa cover lagu tersebut menjadi salah satu bukti dari kesuksesan penggubah lirik terhadap tujuan dari penyampaian pesan yang diharapkan. Proses trending tersebut tentunya memiliki beberapa sebab diatas, salahsatunya ialah liriknya yang membuat baper dan menyentuh (Sadikin, 2020) serta keinginankeinginan untuk disepertikan layaknya sayyidah Aisyah oleh pasanganya. Dalam satu kasus adalah Salah satu cerita yang dimuat oleh media Satu Banten, bahwa salah satu perempuan menyampaikan tentang kegandrungannya terhadap lagu tersebut, yang akhirnya membuat dirinya mempelajari kisah-kisah Sayyidah Aisyah di media, entah melihat ceramah di Youtube atau tulisan-tulisan di internet, diantaranya kata Ayu, bagaimana romantisnya Rosululallah saat menutupi Aisyah dengan jubahnya saat melihat para sahabat sedang berlatih berperang (Imans, 2020).

Hal inilah yang kemudian menjadi salah satu potret yang digambarkan oleh masyarakat terhadap lagu tersebut. Dimana terjadi suatu dorongan yang dimaknai secara luas oleh masyarakat untuk memviralkan lagu tersebut secara tidak sadar (psikoanalisis), yang sebenarnya setelah melihat makna teks dari "tek" lirik lagu, tingkah dari masyarakat terhadap lagu tidak lagi berdasar pada menyukai lagunya, tapi masuk kedalam pelanggengan teks "perempuan shalihah" versi lirik lagu, yaitu perempuan hanya berkisar pada fisik, dan yang senantiasa menemani pasangan, maka merekalah perempuan yang bisa "membahagiakan" pasangannya.

Bentuk ketidakadilan terhadap perempuan

Pemaknaan teks yang diwacanakan oleh sebagian masyarakat terhadap lagu merupakan salah satu wujud tersampainya pesan dari komunikator (penggubah lirik), maka dalam hal ini terdapat proses pembuatan makna dengan pemilihan kata dan penggunaan retorika. Melalui analisis terhadap teks lagu, ditemukan suatu diksi-diksi yang tendensius terhadap subordinasi perempuan, seperti pada unsur fisik (cantik, kulit putih, dan pipi yang kemerahan) serta konteks perempuan yang digambarkan oleh lagu tentang 
unsur patriarkhi (senantiasa membersamai suami hingga kematian yang memisahkan), yang kemudian memunculkan konteks pemaknaaan tentang wilayah perempuan hanyalah perihal domestik yang menemani, mengurusi, dan melayani suami di rumah. Konsep ini membuat paradigma baru bagi sebagian masyarakat tentang makna "perempuan shalihah". Hal ini diperkuat dengan teks bahwa unsur fisik dan sistem patriarkhi tersebutlah yang membuat relasi bahagia sehingga mampu disayangi oleh laki-laki, hal ini berseberangan dengan makna shalihah yang dijelaskan oleh agama.

Ketidakadilan terhadap perempuan dalam teks tersebut, telah dijelaskan dalam teori relasi bahasa dan gender dimana bahasa perempuan dibedakan dengan laki-laki karena beberapa hal, yaitu teori dominasi yang mengatakan bahwa laki-laki cenderung memiliki kekuasaan, sehingga perempuan harus menjelaskan posisi keberadaannya agar diakui sebagai perempuan, teori perbedaan dalam segi biologis dan sosiologis, dimana laki-laki lebih agresif karena ketidakseimbangan hormon dalam dirinya, sedangkan perempuan dihadirkan dengan sikap lebih sopan, akhirnya pada sikap "agresif" dan semangat inilah laki-laki lebih dihormati pada tataran sosialisasinya, seperti kasus laki-laki lebih dominan untuk menginterupsi perempuan, sedangkan perempuan lebih memilih diam setelah diiterupsi. Lalu, teori gender yang memberikan perbedaan terhadap pemaknaan perempuan, yang dipengaruhi oleh agama, latarbelakang, kebangsaan, kelas, orientasi seksual dan kultur wilayah tertentu (Firman, 2016).
Dalam bukunya Betty Friedan (1921-2006) yang berjudul "Feminime Mistique" yang menggagas kepada perempuan untuk keluar dari konsep "mistik" yang beranggapan bahwa tugas istri dan ibu merupakan tugas mulia yang tidak pernah berakhir yang memberikan mereka kepuasan. Kemudian, buku ini salah satu yang menjadikan alasan orang Amerika keluar rumah untuk mencari pekerjaan, inilah yang kemudian disebut sebagai gerakan feminisme liberal moderen. Sedangkan dalam feminisme psikoanalisist menekankan bahwa kultur patriarkat adalah sumber masalah yang menentukan identitas perempuan dan menjadikannya sebagai pemeran pasif, menderita dan narsis. Perasaan inferior dalam diri perempuan didasari oleh kultur dan interpretasi dari kultur biologi bukan biologi itu sendiri seperti yang dikatakan Freud, untuk itu transformasi psikologi perempuan mutlak untuk kemerdekaan perempuan (Amin, 2013).

Masyarakat yang patriarkhi telah menyuguhkan satu dogma bahwa lakilaki merupakan pemimpin yang mengatur, menjaga dan memelihara perempuan, sehingga memberi implikasi pada perempuan untuk menderita neorotik dan tidak bisa keluar dari cengkeramannya. Selama sistem patriarkhi masih ada, maka kondisi perempuan akan tetap demikian. Sedangkan melalui Feminisme Postmodern menganggap bahwa termarjinalkannya posisi perempuan dibentuk oleh struktur narasi-narasi besar budaya yang dibangun oleh bahasa laki-laki, dimana perempuan dianggap tidak memiliki peran. Maka jalan keluar terbaik adalah merekonstruksi bahasa tersebut, menurut Derride salah satunya 
adalah dengan merekonstruksi teks perempuan itu sendiri (Amin, 2013).

Maka pada posisi ini, Kalis Mardiasih memberi warna baru bahwa perempuan tidak hanya berkisar pada yang digambarkan oleh lirik saja, yang cantik paras dan penurut hingga melupakan hak-hak perempuannya. Salah satu dalam bukunya yang berjudul Muslimah yang diperdebatkakn (2019) menuliskan bahwa perempuan adalah manusia dengan pengalaman ketubuhannya sendiri. Perempuan mengalami menstruasi, kehamilan, dan menyusui. Sejak perempuan lahir, kehadirannya di dunia dibayar kontan dengan berbagai stigma dan kewajiban : bahwa perempuan harus begini, perempuan sebaliknya tidak boleh begini. Perempuan harus atau sebaliknya tidak boleh melakukan sesuatu hanya untuk melestarikan struktur sosial maskulin yang telah mapan.

Keluarga juga merupakan elemen terkecil dalam sebuah peradaban, dan perempuan kemudian menjadi sosok yang paling menentukan dalam kontestasi ini. Perempuan yang terlalu terpapar dengan dunia modern dan mengalami keterbukaan dianggap potret pendosa dan sesat, sedangkan yang hanya diam dirumah dan melayani suami setiap saat adalah potret perempuan baik - baik yang "menjaga kehormatannya" (Mardiasih, 2019).

Islam sendiri mengajarkan kepada umatnya untuk tidak diskriminatif terhadap perempuan, jika dahulu perempuan hanya dikatakan sebagai barang yang dimiliki, maka pasca kehadiran Islam, perempuan adalah manusia yang bermartabat. Perempuan layak diberi tempat dan disedarajatkan dengan laki-laki dalam beberapa kondisi, baik ekonomi, pendidikan, sosial politik, serta akses publik lainnya. Kesetaraan laki-laki dan perempuan dicerminkan betul melalui setiap dalidalil naqli, bahwa keduanya adalah manusia terhormat dan bermartabat, terlepas bagaimana bentuk fisik dan nalarnya (Kodir, 2019).

\section{Kesimpulan}

Melalui Analisis wacana Teun A. Van Dijk kita mampu membongkar ketidakberesan yang terjadi ditengahtengah kehidupan masyarakat, menanyakan lebih detil apa yang yang terjadi didalamnya hingga memunculkan problematika, diantaranya dengan membongkar makna teks, kognisi seseorang dalam membawa wacana, dan pembongkaran terhadap konteks yang diwacanakan oleh masyarakat.

Dalam hal ini lirik lagu "Aisyah Istri Rasulullah" ketika dianalisis dari segi teksnya menunjukkan ketidakadilan terhadap perempuan, karena teks menonjolkan perempuan dari sudut pandang unsur fisik dan sistem patriarkhi. Kognisi sosial dari salah satu objek telaah merupakan hal penting untuk sampai membongkar konteks wacana sosialnya, dalam hal ini adalah Kalis Mardiasih sebagai tokoh campaigner terhadap kesetaraan gender. Kemudian ironinya konteks yang diwacanakan oleh sebagaian masyarakat justru memperkuat ketidakadilan tersebut, dalam hal ini dilihat dari respon sebagian masyarakat yang afirmasi terhadap kesamaan pesan lirik tersebut dengan kehidupan realitas mereka.

Selain itu perwujudan makna istri shalihah "versi lagu" bertolak belakang dengan makna shalihah sebenarnya yang dijelaskan oleh agama, sehingga 
menciptakan paradigma terhadap konsep perempuan shalihah "baru". Jadi, secara garis besar lagu Aisyah Istri Rasulullah berimplikasi pada pelanggengan terhadap konsep ketidakadilan bagi perempuan. . Sehingga manusia dituntut untuk lebih jeli dan kritis terhadap penggunaan dan pemaknaan suatu kata tertentu untuk kemalahatan bersama.

\section{Referensi}

'Adawiyah, R. (2010). Profil Wanita Shalihah: Analisis Kepribadian Fatimah Az-Zahra Binti Rasulullah Saw Dan Peran Edukatifnya Dalam Keluarga ( Sebuah Kajian Sejarah ) (Skripsi, UIN Walisongo). UIN Walisongo, Semarang. UIN Walisongo. Retrieved from http://eprints.walisongo.ac.id/3272/3/ 63111071_Bab2.pdf

Aditia, A. (2020, April 7). Syakir Daulay Jelaskan Alasan Lagu Aisyah Istri Rasulullah Tanpa Titel Cover [Artikel Berita]. Retrieved November 27, 2020, from Kompas.com website: https://www.kompas.com/hype/read/ 2020/04/07/223639366/syakirdaulay-jelaskan-alasan-lagu-aisyahistri-rasulullah-tanpa-titel?page $=$ all

Al-Bahjah TV. (2020). Lirik Lagu dan Video "Siti Aisyah Istri Rasulullah" menuai Kontroversi? Inilah Tanggapan Buya Yahya [Video]. You Tube. Retrieved from https://www.youtube.com/watch?v= XLVrwlDPFW8

Amin, S. (2013). Pasang Surut Gerakan Feminisme. Jurnal Marwah, Vo. 12 No. 2. UIN Sultan Syarif Kasim Riau. http://dx.doi.org/10.24014/marwah.v $12 \mathrm{i} 2.520$
Astika, A. (2020, April 7). 4 Fakta Menarik Soal Lagu "Aisyah Istri Rasulullah" Yang Jadi Trending [Artikel Berita]. Retrieved November 27, 2020, from Sonora.id website: https://www.sonora.id/read/42209459 9/4-fakta-menarik-soal-lagu-aisyahistri-rasulullah-yang-jaditrending?page $=$ all

Dwiana, R. (2020, April 13). Viralnya Lagu Aisyah Istri Rasulullah [Berita]. Retrieved April 24, 2020, from Republika.co.id website: https://republika.co.id/berita/q8oxjg4 14/viralnya-lagu-emaisyah-istrirasulullahem

Eriyanto. (2011). Analisis Wacana; Pengantar Analisis Teks Media. Yogyakarta: LkiS Group.

Firman, F. (2016). Analisis Wacana Ideologi Bahasa Perempuan. Jurnal Al-Maiyyah, Vo. 9 No.1. https://doi.org/doi.org/10.35905/alma iyyah.v9i1.331

Gani, A. (2020, April 8). Analisis Serius Soal Makna Lagu Aisyah Istri Rasulullah [Kolom]. Retrieved June 21, 2020, from Mojok.co website: https://mojok.co/terminal/analisisserius-soal-makna-lagu-aisyah-istrirasulullah/

Garjito, D., \& Aditya, R. (2020, April 8). Lagu Aisyah Istri Rasulullah Tuai Polemik, Buya Yahya Sarankan Begini [Berita]. Retrieved June 21, 2020, from Suara.com website: https://www.suara.com/news/2020/04 /08/190156/lirik-lagu-aisyah-istrirasulullah-tuai-polemik-buya-yahyasarankan-begini

Imans, D. (2020, April 2). Lagi Viral Di YouTube, Ini Tanggapan Wanita Jaman Now Tentang Aisyah Istri Rasulullah [Berita]. Retrieved June 
17, 2020, from Satu Banten.com website: https://satubanten.com/lagiviral-di-youtube-ini-tanggapanwanita-jaman-now-tentang-aisyahistri-rasulullah/

Jorgensen, M. W., \& Phillips, L. J. (2007). Analisis Wacana; Teori dan Metode. Yogyakarta: Pustaka Pelajar.

Kodir, F. A. (2019). 60 Khadits Shahih; khususu tentang Hak - Hak perempuan dalam Islam dilengkapi penafsirannya. Yogyakarta: Diva Press.

Ma'arif, B. S. (2010). Komunikasi Dakwah; Paradigma Untuk Aksi. Bandung: Simbiosa Rekatama Media.

Magdegani, D. P. (2020, April 7). Lagu Aisyah Istri Rasulullah Viral, 15 Artis Ini Ikut Cover dan Jadi Trending Youtube [Berita]. Retrieved April 24, 2020, from Merdeka.com website:

https://www.merdeka.com/sumut/lag u-aisyah-istri-rasulullah-viral-15artis-ini-ikut-cover-dan-rajaitrending-di-you.html

Mardiasih, K. (2019). Muslimah yang Diperdebatkan. Yogyakarta: Buku Mojok.

Mardiasih, K. (2020). Lagu Aisyah Istri Rasulullah viral karena liriknya romantis. website: https://web.facebook.com/kalis.mardi asih/posts/10215861510283016

Meleong, L. J. (2002). Metode Penelitian Kualitatif. Bandung: Remaja Rosdakarya.

Mulyana, D. (2000). Ilmu Komunikasi; Suatu Pengantar. Bandung: Remaja Rosdakarya.

Musyafa'ah, N. (2017). Analisis Wacana Kritis Teun A. Van Dijk "Siswa Berprestasi Jadi Pembunuh."
Modeling, Jurnal Pogram Studi PGMI, 4(2).

Sabyan. (2020). Aisyah Istri Rasulullah-Cover [Video]. Sabyan Youtube. Retrieved from https://www.youtube.com/watch? $\mathrm{v}=\mathrm{a}$ NOZnoRg_IY

Sadikin, R. A. (2020, March 31). 6 Fakta di Balik Lirik Lagu Aisyah Istri Rasulullah, Diburu Warganet! [Berita].

Safitri, D. S. (2019). Lirik Lagu "2019 Ganti Presiden" Karya Sang Alang: Kajian Wacana Teun A. Van Dijk (Skripsi, m). m, Sumatera Utara. Universitas Muhammadiyah Sumatera Utara (UMSU). Retrieved from

http://repositori.umsu.ac.id/xmlui/han dle/123456789/823

Sobur, A. (2001). Analisis Teks Media; Suatu Penagntar untuk Analisis Wacana, Analisis Semiotik dan Analisis Framing. Bandung: Remaja Rosdakarya.

Supintou, A. (2020, April 7). Viral, Fakta dan Lirik Lagu Aisyah Istri Rasulullah Versi Sabyan [Berita]. Retrieved April 24, 2020, from IDN Times Jogja website: https://newsmaker.tribunnews.com/2 020/04/07/viral-lagu-aisyah-istrirasulullah-buya-yahya-berharapliriknya-diubah-saya-tidak-tegamembacanya

Syahrul S., H. (2018). Psikoanalisis Sigmund Freud dan Implikasinya Dalam Pendidikan. In ResearchGate (p. 2). Retrieved from https://www.researchgate.net/publicat ion/323535054_Psikoanalisis_Sigmu nd_Freud_dan_Implikasinya_dalam_ Pendidikan 
Wikipedia. (2020). Kalis MardiasihAutobiografi [Ensiklopedia Bebas]. Retrieved June 29, 2020, from Wikipedia website: https://id.wikipedia.org/wiki/Kalis_M ardiasih\#: :text=Kalis\%20Mardiasih \%20adalah\%20seorang\%20penulis,d an\%20pendiri\%20Partai\%20Kebangk itan\%20Bangsa). 
This page intentionally left blank. 